\title{
FILTRATION OF A BACTERIAL FERMENTATION BROTH: HARVEST CONDITIONS EFFECTS ON CAKE HYDRAULIC RESISTANCE
}

\author{
M.MEIRELES ${ }^{1}$, E. LAVOUTE, P. BACCHIN \\ Laboratoire de Génie Chimique UMR 5503 Université Paul Sabatier- 118 route de \\ Narbonne 31062 Toulouse cedex, France \\ meireles@chimie.ups-tlse.fr \\ Phone : +33561558162 Fax : +33561556139
}

\begin{abstract}
The hydraulic resistance of cakes formed during the ultrafiltration of Streptomyces pristinaespiralis broths has been investigated for different harvesting conditions. Streptomyces pristinaespiralis broth was harvested after the point of microorganism activity declines (0-h aged broth) and held for different durations after that, up to 16 hours (16 aged broths). Aging behavior occurring between the end of microorganism activity and harvest was compared for different acidification procedures $(\mathrm{pH})$ and the mechanisms by which cake hydraulic resistance is affected. For broths harvested under conditions where the acidification is fixed at $\mathrm{pH} 2$ or 3 , hydraulic resistance associated with cake build up is directly determined by the cells interactions. Holding broths beyond 5 hours contributes to a release of a soluble component from the cell surface. Enhanced cell surface interactions then turn the cake structure into a more open one and reduce the specific hydraulic resistance. For broths harvested under conditions where the acidification is fixed at $\mathrm{pH} 4$, hydraulic resistance associated with cake build up is both determined by cell interactions and cell morphology. The cause of the increase in specific hydraulic resistance with aging is due to the binding of a soluble component released by the micro-organisms which decreases the cell surface interactions.
\end{abstract}

Keywords: Ultrafiltration, Cake hydraulic resistance, Biotechnology, Harvest time

\footnotetext{
${ }^{1}$ Corresponding author
} 


\section{Introduction}

Fermentation processes are increasingly involved in the production of high value bioproducts such as pharmaceuticals. Separation of cells from soluble broth components may be achieved by conventional methods (rotating filter, sedimentation and centrifugation) but such recovery techniques must account for the often-labile nature of the bioproducts, the generally low concentration levels and the complex composition of the media. Membrane filtration is increasingly used for separation and concentration of cells from a fermentation broth as it offers advantages over classical processes. Though, one of the main factors that greatly affects the operating costs is the magnitude of permeate flux that can be achieved. Indeed when filtering fermentation broth, the permeate flux can be severally limited by membrane fouling and cake formation.

Marshall et al.[1] and Belfort et al.[2] have discussed some crucial factors that determine flux limitations owing to different mechanisms and different nature of fluid (particle or colloidal suspensions, macromolecular solutions). For the ultrafiltration of cells or microorganisms both the build-up of a cell cake layer and internal fouling of the membrane by soluble broth components contribute to the hydraulic resistance of filtration. In some recent studies, critical factors for the cake layer hydraulic resistance such as cell morphology and particle surface properties have been identified. Nakanishi et al. [3] showed that filtration hydraulic resistance depends on the size and shape of microorganisms, which indirectly determine the void fraction in the cake. For cross flow filtration, Tanaka et al. [4] revealed that rod-shaped particles orientate in the direction of flow. Cake filtration hydraulic resistance then appears to be higher than for cakes of ellipsoidal particles. Mc Carthy et al.[5] correlate the compressible nature of a cell cake to the aspect ratio of the cell present in the initial suspensions. Particle surface properties also play a role in hydraulic resistance to filtration. For submicron particles Bacchin et al [6] describes the effects of surface interactions on the rate of particle deposition in the cake. For cells, the link between the surface charge, cake morphology and cake hydraulic resistance has also been invetigated by Ohmori et al. [7]. Interactions between cells and soluble broth components can also influence the hydraulic resistance to filtration. Because of the complex composition and the large number of material in fermentation broth, the 
nature of these interactions is very difficult to assess. Several authors [8], [9],[10] have evidence that for mixture of protein and yeast cells, protein fouling of the membrane and total filtration hydraulic resistance are reduced in the presence of cells. This is attributed to the preventive effect of the cells towards both internal fouling and protein cake build-up on the membrane. However for differents types of mixture like mixture of molasse and yeast [11], or protein and clay [12], the authors observe that the hydraulic resistance can be increased for the mixture or can depend on physico-chemical conditions.

Broth harvesting conditions including aging time, $\mathrm{pH}$, temperature, stirring conditions, can influence both the morphology of cells and the release of intracellular components. It is well known that starving or damaged cells can release cell components. Recently Okanoto et al. [13] show that exposure to nutrient poor broth during cell holding results in changes in filtration hydraulic resistance as a consequence of DNA release. Their hypothesis is that broth handling, in particular exposure to nutrient poor broth during cell holding/harvesting may result in cell surface changes during aging. Changes in filtration hydraulic resistances were then attributed to the impact of DNA release on particle surface charge. Efforts have been made to determine which type of mechanism would thus contribute to an increase in filtration hydraulic resistance associated with a cake build-up.Very few studies have indeed investigated the effects of harvesting conditions on the aging behavior of a fermentation broth and the consequences in terms of an increase in fouling and the nature of fouling mechanisms. In this work we have investigated the effects of harvesting conditions on the filtration hydraulic resistance of Streptomyces pristinaespiralis broth. The objective was to determine whether holding broths in varying conditions after the microorganism activity was stopped by an acidification of the media would affect the filtration associated with a cake build up. Additionaly we aimed to determine whether the cause of any changes was the result of changes in the cell or due to the release of components during this period of time. 


\section{Experimental}

\subsection{Fermentation broths}

The fermentation broths used in this work were kindly provided by Aventis Pharma (CRP Vitry) from a Streptomyces pristinaelis strain. The seed culture medium contains raw matter from initial yeast cream and glucose. During the growth phase of the organism, 50 $\%$ of sugar is absorbed by the biomass and $50 \%$ is degraded on CO2 by respiration. An antibiotic is produced through a secondary mechanism. The rate of production is highest when the microorganism activity starts to decline. Fermentation is then stopped when the target product concentration no longer varies. This is achieved by fixing the $\mathrm{pH}$ in the fermentation tank around 4. (Indeed at the scale of industrial production, the control of $\mathrm{pH}$ in a fixed range is not trivial and sampling in the holding tank for several productions revealed that $\mathrm{pH}$ value actually is in the range 2 to 4 .)

The fermentation broth is then held at $17^{\circ} \mathrm{C}$ for a period, which depends on the availability of downstream separation steps. This holding time may last up to 16 hours depending of downstream step availability (Figure 1). The downstream process consists of several filtration steps designed to recover separately biomass and culture broth, which is ultimately refined. In this downstream process, $\mathrm{pH}$ is maintained to a value of 3 which was shown to be an optimum between the target solubility, enzymatic stability and degradation. For this study, Aventis Pharma directly supplied fermentation batches from industrial 100 liters reactors. Collected samples were filtered at 0 and $16 \mathrm{~h}$ "aging time" where "aging time" is the duration between harvest and filtration.

\subsection{Filtration system}

The filtration experiments were carried out using a 300ml stirred cell $(41.8 \mathrm{~cm} 2$ filtration area) (Amicon, France) with 100000 Dalton molecular weight cut-off polyethersulfone membranes (Techsep-St Maurice de Beynost, France). Before first use, membranes were rinsed with distilled water to remove any trace of preservatives. Then a compacting procedure was carried out by filtration of distilled water for an hour at a transmembrane pressure of 2 bars. This procedure is necessary to ensure that the membrane porous 
structure did not vary when filtration tests were carried out at transmembrane pressures lower than $200 \mathrm{kPa}$. Before each experiment, membranes were pre-fouled according to the following procedure: $300 \mathrm{ml}$ of broth was concentrated 3-fold at a transmembrane pressure of $100 \mathrm{kPa}$ bar and was then kept in contact with the membrane for 12 hours. This procedure was used to ensure that no interactions between soluble components and internal structure of porous membrane occur during the course of subsequent filtration. It was followed by the measurement of the flux of deionised water at $\Delta \mathrm{P}=100 \mathrm{kPa}$. Filtration tests were subsequently carried out according to the following procedures. $150 \mathrm{ml}$ of broth were introduced in the filtration cell, and then filtration started. The experiments were conducted at constant room temperature $\left(20^{\circ} \mathrm{C}\right)$ under constant pressure conditions by applying pressurized air (200 kPa). Cumulative permeate weight was recorded on a balance as a function of time and filtration flux was deduced from these variations. Filtration was stopped when cumulative permeate weight reaches a value of $60 \mathrm{ml}$. Cleaning procedure was then performed (Ultrasil $10-8 \mathrm{~g} / \mathrm{l})$ at high temperature $\left(30-35^{\circ} \mathrm{C}\right)$.

\subsection{Optical microscopy}

Morphological characteristics were observed owing to an optical microscope (Axiolab A 6 Reflected Light Microscope Zeiss, Zeiss) equipped with a video camera (Camera CCDIRIS Sony, Sony Corp., Japan). Prior to each observation, broth samples were first centrifuged and then diluted with deionised water for correct spreading on slides. After airdrying of the slides, Ziehl's carbon Fuschin was poured on the slide and rinsed with water after one minute. Magnification of $1000 \mathrm{X}$ was used with an oil-immersed lens.

\subsection{Protein assays}

Protein concentration of supernatants obtained from the centrifugation of broths samples achieved at $6000 \mathrm{rpm}$ and $4^{\circ} \mathrm{C}$ during $30 \mathrm{~min}$ (Refrigerated Centrikon, Kontron Instruments) was assayed by the Coomassie G-250 Protein Assay (Biorad, Germany) against serial dilution of a BSA standard. 


\subsection{Dry cell mass in slurry}

To measure the dry cell mass in slurry, harvested broth samples were washed with $8 \mathrm{~g} / \mathrm{l}$ Nacl. Washing was carried out by centrifugation at $4000 \mathrm{~g}$ with three cycles of resuspending in approximatively the original volume of $8 \mathrm{~g} / \mathrm{l} \mathrm{Nacl}$. Dry cell mass in slurry was then obtained by drying at $105^{\circ} \mathrm{C}$ (Moisture Analyser HR 73, Metter Toledo, Switzerland). Dry cell mass in slurry are expressed in g of dry cell mass / g of suspension.

\section{Effects of harvesting on filtration hydraulic resistance associated with cake build up}

Filtration theory was used to relate the rate of flux decline to the hydraulic resistance associated with the cake buildup. For dead-end unstirred filtration, it is generally assumed that the permeate flux at any time t, is described by a Darcy's law for flow through two porous media [14](cake and membrane) in series:

$J=\frac{d V}{A d t}=\frac{\Delta P}{\mu\left(R_{m}+R_{c}\right)},(1)$

Membrane hydraulic resistance $\mathrm{R}_{\mathrm{m}}$ can be obtained from the pure water flux through the pre-fouled membrane just before filtration, $\mathrm{J}_{\mathrm{wf}}$, as :

$\mathrm{R}_{\mathrm{m}}=\frac{\Delta \mathrm{P}}{\mathrm{J}_{\mathrm{W}, \mathrm{f} \cdot \mu}},(2)$

For a constant transmembrane pressure, integration of Eq.(1) gives :

$\frac{t}{V / A}=\frac{1}{J_{w}}+\frac{\mu R_{c}}{2 \Delta P}\left(\frac{V}{A}\right),(3)$

Figure 2 shows typical plots of $\mathrm{t} /(\mathrm{V} / \mathrm{A})$ versus V/A during filtration. Data analysis based on equation (3) assumes this plot being linear. Some authors have reported that it was not always true implying differing period for cake build-up mechanism: an early period caused by the contact between broth components and membrane material and a subsequent period 
caused by cake deposition. This was ruled out in this study as a static pre-contact procedure was used before filtration.

Table 1 summarizes the results from filtration runs in terms of cake hydraulic resistance $R_{c}$ for a filtered volume of $60 \mathrm{ml}$. A specific nomenclature is used where for instance, the sample B2-5 is a broth held at $\mathrm{pH} 2$ during 5 h-aging time. The comparison of data shows that the cake filtration hydraulic resistance is nearly divided by 2 after a minimal aging time of 5 hours for the broth held at $\mathrm{pH} 3$, and 7 hours for broth held at $\mathrm{pH} 2$ where as for broth held at $\mathrm{pH} 4$, the cake hydraulic resistance decreases in an early stage and then increases up to $80 \%$ of the initial value.

The decrease in hydraulic resistance associated with a cake build-up observed for broths aged at $\mathrm{pH} 2$ or 3 or in the early stage for broth aged at $\mathrm{pH} 4$ could be related to a change in the cell morphology, to a modification of the interaction between cells and broth soluble components or to a modification of soluble components during the aging process.

A change in the cell morphology is most likely evident in the optical micrographs shown in Figure 3. For the broth held at $\mathrm{pH} 4$, micrographs show a drastic change from a structure of hyphae in pellets at 0h (Figure 3:broth B0-4) to a hatched and divided network at 16 hours (Figure 3:broth B16-4). Changes also appear for broths held at pH 2 or 3. However in these conditions, it seems most likely indisputable to a decompaction of the hyphae more than a lysis of the filaments, long and tangled filaments are evidenced in micrographs of B2-16 and B3-16 broths. A modification of cell charge during aging might be an explanation for these changes. The protein assays of supernatants of the broths hold at different $\mathrm{pH}$ values show that the soluble protein concentration changes during the aging are most significant for broths aging at $\mathrm{pH} 4.0$ (Table 2).

As pointed out earlier, the changes in protein content might be very well affected by cell starvation and damaged. Okamoto et al. [13] have shown that an exposure to nutrient poor broth during cell holding can induce changes in produced broth components.

Based on our observations it is proposed that the changes in the cell during aging is largely responsible for variations in filtration hydraulic resistance associated with the cake buildup. At this stage of the study, we do not really have more information about the biochemical and physico-chemical reactions leading to this cell change. However we could observe for the conditions when no filament lysis occurs, an abundance of yeasts in the 
aged broth whereas they were quite scarce when hatched filaments are observed in the broth. The hypothesis we propose states that when broths are harvested and held at $\mathrm{pH} 4$, biological activity is not completely stopped and aging process results in filament lysis accompanied by an increase in soluble protein content.

\section{Mechanisms increasing cake hydraulic resistance}

Based on our observations of the changes in the cell morphology and in the protein content during aging, one can consider different mechanisms for hydraulic resistance associated with cake build up:

1. alteration of cake structure by changing cell morphology or compaction of the hyphae

2. alteration of cake structure by deposition of soluble component within the cake.

An estimation of the impact of an alteration of cake structure on hydraulic resistance can be estimated through Kozeny-Carman equation[15]:

$\frac{\mathrm{R}_{\mathrm{C}} \mathrm{A}}{\rho . \mathrm{m}}=\frac{\mathrm{k}_{0}(1-\varepsilon)^{2}}{\varepsilon^{3}} \mathrm{~S}_{\mathrm{v}}^{2},(4)$

where $R_{c}$ is the hydraulic resistance associated with the cake build up, $\mathrm{k}_{\mathrm{o}}$ is the Kozeny constant commonly taken as $5, \rho$ is the density of cell assumed as $1000 \mathrm{~kg} \cdot \mathrm{m}^{-3}$. The cake mass parameter, m, was calculated from dry cell weight in the broths (around $0.05 \mathrm{~g} / \mathrm{g}$ on average) and from cumulative permeates weight $(60 \mathrm{ml})$ for each experiment. $S_{v}$ the specific surface area of cell and $\varepsilon$ the void fraction of cake have been determined for $16 \mathrm{~h}$ aged broths by Lavoute et al. [16],Table 3.

From these data, equation (3) would predict for $16 \mathrm{~h}$ aged broths an hydraulic resistance of 2.09.10 $0^{+9} \mathrm{~m}-1$ for B2-16, $1.610^{9} \mathrm{~m}-1$ for B3-16 and $2.110^{+9} \mathrm{~m}-1$ for B4-16 when experimental filtrations give respectively $1.10^{+9}, 6.410^{+9}$ and $1.810^{+10} \mathrm{~m}-1$. From these calculations, we might infer that the cell changes during aging can quantitatively account for the decrease in hydraulic resistance observed for B2 and B3 broths.The cause of the decrease in hydraulic resistance that occurs for B2 and B3 broths held beyond 5 hours 
might be determined by a change in the interaction between the aged cells. Release of a component from cell surface after 5 hours of aging would enhance the magnitude of charge repulsion between cells and as a consequence decrease the specific hydraulic resistance of $\mathrm{B} 2$ and B3 aged broths. For broth aged at $\mathrm{pH} 4$, the value predicted for the cake hydraulic resistance is much lower than those obtained from the experiments. Even though a change in cell morphology occurs, void fraction of the cake is still too low to quantitatively aacount for the increase in hydraulic resistance after 7 hours of aging. As pointed out earlier, changes in soluble protein content are most significant for these conditions. Alteration of cake pore structure can thus be promoted by soluble component deposition within the cake. Assessment from equation (3) of the void fraction that would justify cake hydraulic resistance obtained from B4-16 gives a value of 0.15 . However the amount of soluble component is too low to account for a $30 \%$ decrease in void fraction by protein deposition. An alternative explanation would be a modification of interactions between cell and a soluble component binding at the cell surface not present at earlier stage of aging. This is supported by the fact that the lysis can induce the release of components different from those intially present in the broths. Reduced magnitude of cell surface charge due to soluble component binding increases hydrophobicity and decreases charge repulsion predisposing cells to further aggregation[7]. If the aggregation state changes with aging through the increase in soluble protein content, it is possible that no changes have been observable by optical microscopy in the suspended broths since the ratio cell density over protein content is low. Scanning electron microscopy of cakes would be a rather elegant way to clear that point, however it would first require to assess how required preparation of samples including solvent exchange and sputter coating should be handled to ensure that no changes in cake structure occurs during sample preparation.

\section{Conclusions}

For broths harvested in conditions where the acidification is fixed at $\mathrm{pH} 2$ or 3, hydraulic resistance associated with cake build up is directly determined by the cells interactions. Holding broths beyond 5 hours contributes to a decrease in specific hydraulic resistance. This decrease could then be related to a release of a soluble component from the cell surface. Enhanced cell surface interactions would then decrease and turn the cake structure 
into a more open one with a reduced hydraulic resistance. For broths harvest in conditions where the acidification is fixed at $\mathrm{pH} 4$, hydraulic resistance associated with cake build up is both also determined by cell interactions and cell morphology. Optical microscopic observations give evidence that aging directly affects cell morphology through a lysis for broths held beyond 7 hours. However this does not contribute to a decrease in cake void fraction compliant with the order of magnitude for hydraulic resistance. The cause of the increase in hydraulic resistance with aging is more likely due to the binding of a soluble component released by the micro-organisms which decreases the cell surface interactions.

Acknowledgements - This work was supported by an industrial research program (Aventis Pharma, Vitry-sur-Seine, France).

\section{References}

[1] Marschall A.D, Munro P.A,Trägardh G (1993) The effect of protein fouling in microfiltration and ultrafiltration on permeate flux, protein retention and selectivity :a literature review. Desalination, 91: 65-108

[2] Belfort G; Davis R.H; Zydney A.L. (1994) The behavior of suspensions and macromolecular solutions in cross flow microfiltration. J Membr Sci, 96:1-37

[3] Nakanishi K, Takadoro T, Matsuno R (1987) On the specific hydraulic resistance of cakes of microorganisms. Chem Eng Commun. 62:187-201

[4] Tanaka T, Abe K, Akasawa H, Yoshida H, Nakanishi K (1994) Filtration characteristics and structure of cake in cross flow filtration of bacterial suspension. J Fermentation Bioeng, 78:455-461

[5] McCarthy A.A, O’Shea D.G, Murray N.T, Walsh P.K, Foley G (1998) Effect of cell morphology on dead end filtration of the dimorphic yeast Kluyveromyces marxiamus var.marxiamus NRRLy2415. Biotechnol Prog, 14:279-285

[6] Bacchin P, Aimar P, Sanchez V, (1995) Model for colloidal fouling of membranes, AIChE Journal, 53:223-228

[7] Ohmori K, Glatz C.E, (1999), Effects of pH and ionic stregnth on microfiltration of C. glutamicum, J.Membr Sci 153:23

[8] Arora N, Davis R.H (1994) Yeast cake layers as secondary membrane in dead end microfiltration of bovine serum albumin J. Membr.Sci. 92:247-256

[9] Davis R.H, Kuberkar V.T (1999) Effects of added yeast on protein transmission and flux in cross flow membrane microfiltration, Biotechnol.Prog. 15:472-479

[10] Güell C, Czekaj, Davis R.H, (1999) microfiltration of protein mixtures and the effects of yeast on membrane fouling, J.Membr.Sci. 155:113-122

[11]Tanaka T, Kamimura R ,Fujiwra R, Nakanishi K (1994) Crossflow microfiltration of yeast broth cultivated in molasses.Biotechnol Bioeng.43:1094-1101.

[12]Causserand C, Jover K, Aimar P, Meireles M (1997), Modification of clay cake permeability by adsorption of protein, J Membr Sci, 137:31-44 
[13] Okamoto Y, Ohmori K, Glatz C.E (2001) Harvest time effects on membrane cake hydraulic resistance of Escherichia coli broth, J.Membr Sci 190:93-106

[14] Darcy H. (1856) , The public fountains of the city of Dijon, Hist. de I'Académie royale des sciences, 1733, 351

[15] Carman, P.C. (1938)Trans.Inst.Chem Eng, 16,168.

[16] Lavoute E, Meireles M , Rheology of concentrated fermentation broths. In submission procedure

\section{Figures legends:}

Figure 1: Scheme of the first steps for downstream processing of the fermentation broth

Figure 2: Treatment of filtration data : example of a plot of t/(V/A) versus V/A during filtration of B2-5 broth. The transmembrane pressure is equal to $100 \mathrm{kPa}$

Figure 3: Optical microscope images of broths samples for different procedures of acification and for different aging times

Table 1: Cake hydraulic resistances obtained from t/(V/A) vs V/A slopes or B2, B3 and B4 samples for different aging times.

Table 2: Soluble protein content for supernatants issued from B2-16, B3-16 and B4-16 broth

Table 3: Specific area and void fraction of cake for B2-16, B3-16 and B4-16 broth.

$\begin{array}{ll}\text { Nomenclature } & \\ \mathrm{A} & \text { membrane area }\left(\mathrm{m}^{2}\right) \\ \mathrm{J} & \text { permeate flux }\left(\mathrm{m}^{3} \mathrm{~m}^{-2} \mathrm{~s}^{-1}\right) \\ \mathrm{J}_{\mathrm{wf}} & \text { pure water flux }\left(\mathrm{m}^{3} \mathrm{~m}^{-2} \mathrm{~s}^{-1}\right) \\ \mathrm{k}_{\mathrm{o}} & \text { Kozeny constant } \\ \mathrm{m} & \text { dry mass of cake }\left(\mathrm{kg}_{\mathrm{kg}} \mathrm{kg}^{-1}\right) \\ \Delta \mathrm{P} & \text { transmembrane pressure drop }(\mathrm{Pa}) \\ \mathrm{R}_{\mathrm{c}} & \text { hydraulic resistance of cake }\left(\mathrm{m}^{-1}\right) \\ \mathrm{R}_{\mathrm{m}} & \text { hydraulic resistance of membrane }\left(\mathrm{m}^{-1}\right) \\ \mathrm{S}_{\mathrm{v}} & \text { specific surface area }\left(\mu \mathrm{m}^{-1}\right) \\ \mathrm{t} & \text { filtration time }(\mathrm{s}) \\ \mathrm{V} & \text { permeate volume }\left(\mathrm{m}^{3}\right)\end{array}$

Greek letters

$\begin{array}{ll}\alpha & \text { specific hydraulic resistance per wet cake mass }\left(\mathrm{m} \cdot \mathrm{kg}^{-1}\right) \\ \varepsilon & \text { void fraction of cell cake } \\ \mu & \text { viscosity of permeate (Pa.s) } \\ \rho & \text { density of wet cell cale }\left(\mathrm{kg} \cdot \mathrm{m}^{-3}\right)\end{array}$


0h aging sample

B2-0

3.12

B3-0

2.04

B4-0

2.02

$5 \mathrm{~h}$ aging sample

B2-5

3.04

B3-5

1.90

B4-5

1.00

$7 \mathrm{~h}$ aging sample

B2-7

3.00

B3-7

0.70

B4-7

0.90

$9 \mathrm{~h}$ aging sample

B2-9

0.90

B3-9

0.68

B4-9

1.50

13h aging sample

B2-13

0.10

B3-13

0.62

B4-13

1.80

16h aging sample

B2-16

0.11

B3-16

0.64

B4-16

1.85

Table 1 


\begin{tabular}{lc}
\hline Sample & Protein content in the supernatant $(\mathrm{mg} / \mathrm{ml})$ \\
\hline 16h aging sample & \\
B2-16 & 0.21 \\
B3-16 & 0.24 \\
B4-16 & 0.42 \\
\hline
\end{tabular}

Table 2

\begin{tabular}{lcc}
\hline Sample & specific area Sv $(\mu \mathrm{m}-1)$ & void fraction $\varepsilon$ \\
\hline 16h aging sample & & \\
B2-16 & 8.1 & 0.36 \\
B3-16 & 7.9 & 0.38 \\
B4-16 & 8.0 & 0.45 \\
\hline
\end{tabular}

Table 3 


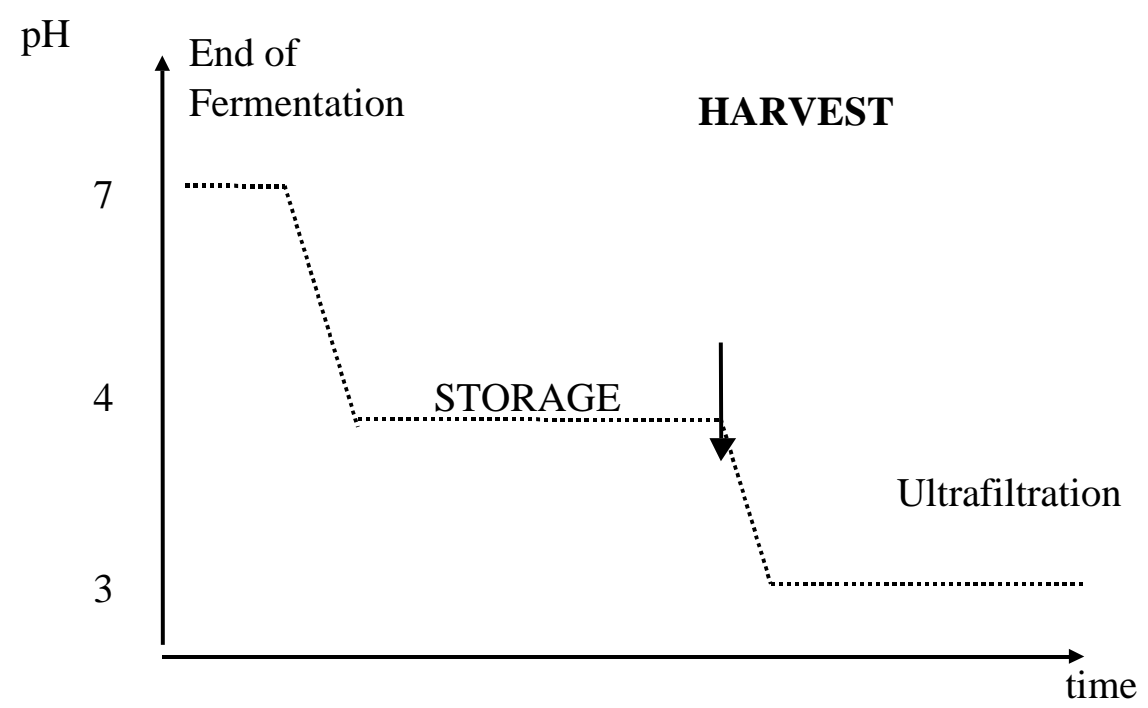

Figure 1

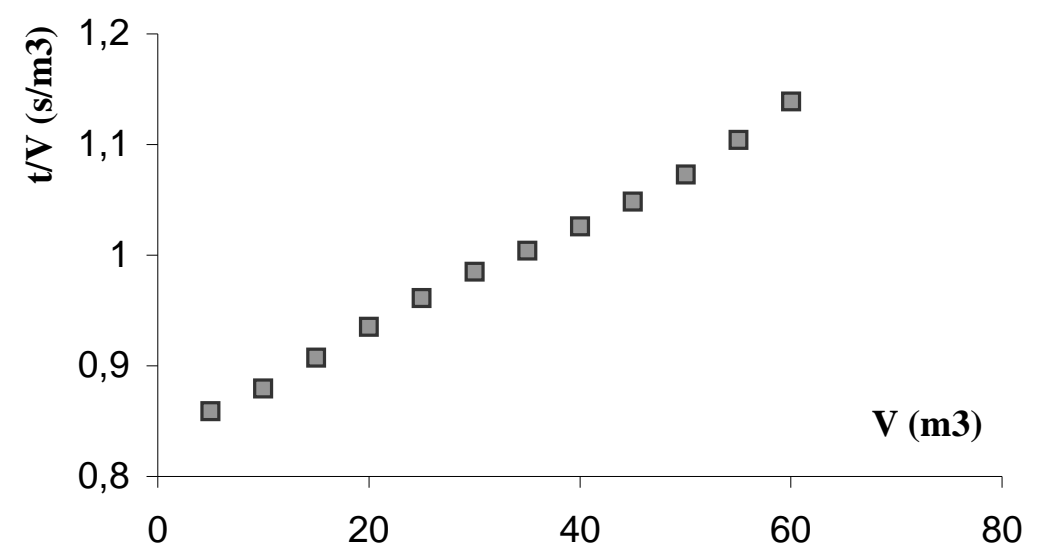

Figure 2 


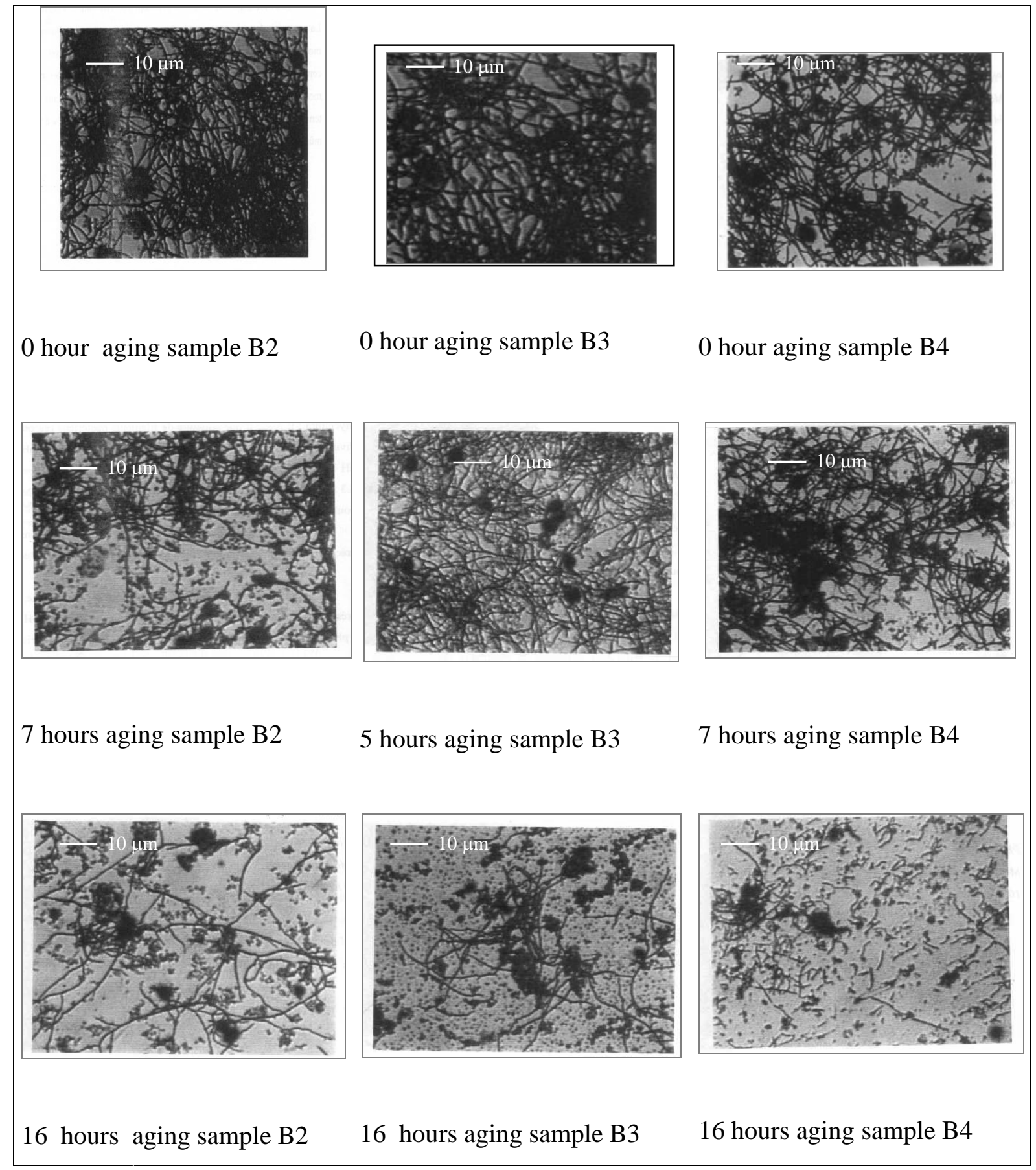

Figure 3 